\title{
Infection by Schistosoma mansoni Sambon 1907 in the First Four Months of Life of Biomphalaria straminea (Dunker, 1848) in Brazil
}

\author{
Monica Ammon Fernandez $/^{+}$, Otávio Sarmento Pieri* \\ Departamento de Malacologia *Departamento de Biologia, Instituto Oswaldo Cruz-Fiocruz, Av. Brasil 4365, \\ 21045-900 Rio de Janeiro, RJ, Brasil
}

Compatibility between Schistosoma mansoni and Biomphalaria straminea when exposed to the parasite on the first four months of age was assessed for five parasitological aspects: indices of infection and mortality, duration of precercarial and cercarial periods, and rate of cercarial emission. Infections were made on molluscs from laboratory colonies, at the following ages: 8, 13, 18, 21, 53, 83 and 114 days. Two B. straminea colonies were used (Camorim, PE and Picos, PI), and one B. glabrata colony (Ressaca, MG) was used as control. The main results are as follows: (I) infection was significantly associated with mollusc age, being proportionally higher in sexually immature than in mature molluscs for the three colonies; (II) for B. straminea from Camorim, mortality did not differ significantly between infected and non-infected snails; for B. straminea from Picos significantly more deaths occurred among infected than among non-infected snails, while the opposite was observed for $\mathrm{B}$. glabrata from Ressaca; (III) for the three colonies, the precercarial period was significantly shorter for immature molluscs than for mature ones; (IV) the duration of the cercarial period was extremely variable for the three colonies; $(V)$ sexual maturity did not influence cercarial emission for the three colonies.

Key words: Schistosoma mansoni - Biomphalaria straminea - compatibility - age - Brazil

One of the factors influencing the intermediate host susceptibility to Schistosoma spp. is the mollusc developmental stage. Archibald and Marshall (1932) were the first ones to observe the decrease of the susceptibility with the mollusc age in the combination Schistosoma haematobium and several species of Bulinus. Other authors (Moore et al. 1953, Chu et al. 1966, Raymond \& Probert 1992) confirmed that observation and pointed out other parasitological aspects: survival, duration of the precercarial period and cercarial emission.

However, the influence of age in the combination Schistosoma mansoni-Biomphalaria is not completely defined. Newton (1953), using Biomphalaria glabrata, proved that molluscs at the age of 1 to 9 days are highly susceptible and the infection rate on older snails is significantly lower. Richards (1970) identified four categories of susceptibility of $B$. glabrata to $S$. mansoni: (1) non susceptible at any age; (2) juvenile susceptible/

\footnotetext{
This work is part of the main author's MSc thesis The authors dedicate this paper to the Oswaldo Cruz Institute in honor of the centenary of its foundation, May 25th 1900.

${ }^{+}$Corresponding author. E-mail: ammon @ioc.fiocruz.br Received 14 May 2001

Accepted 25 July 2001
}

adult non susceptible; (3) susceptible at any age; and (4) juvenile susceptible/adult variable. According to Michelson and Dubois (1978) refractory populations show different degrees of susceptibility when submitted to experimental infection in newly-hatched molluscs. According to Niemann and Lewis (1990), B. glabrata susceptibility and S. mansoni cercarial production are strongly influenced by the size of the host and not by its age. Chernin and Antolics (1975) and Richards (1973), using Biomphalaria straminea colonies, emphasized the importance of young molluscs in the $S$. mansoni transmission dynamics. More recently, Fernandez (1997), using B. glabrata, Biomphalaria tenagophila and B. straminea exposed to $S$. mansoni sympatric miracidia at the age of 1,2 and 3 months, observed a decline in the susceptibility of B. glabrata and an increase in Biomphalaria tenagophila; for B. straminea no significant differences on the infection index were found.

In order to bring subsidies to clarify the bearing of immature molluscs on the dynamics of S. mansoni transmission, this study has investigated comparatively the compatibility between B. straminea and S. mansoni when exposed to the parasite on the first four months of age, including immature and mature stages. Five parasitological aspects were assessed: indices of infection and 
mortality, duration of precercarial and cercarial periods, and rate of cercarial emission.

\section{MATERIALS AND METHODS}

Snails populations - Two B. straminea colonies were used (Camorim - São Lourenço da Mata, State of Pernambuco and Picos, State of Piauí), and one B. glabrata colony (Ressaca - Belo Horizonte, State of Minas Gerais) was used as control. The used snails were from colonies previously established in the Department of Malacology, Instituto Oswaldo Cruz. The colony from Camorim had been kept for approximately four years, while the others, for more than 13 years. The procedures for breeding the test specimens were described by Fernandez (1997).

Experimental infection - When the snails were $8,13,18,21,53,83$, and 114 days old, they were individually measured and exposed to five $S$. mansoni sympatric miracidia of the EC strain (B. straminea from Picos), of the CM strain (B. straminea from Camorim) and of the $\mathrm{BH} 2$ strain (B. glabrata). The EC and $\mathrm{BH} 2$ S. mansoni strains were isolated as described by Fernandez (1997). The CM S. mansoni strain was isolated on August 13, 1993 from feces of CM Braga, 4 years, born and grown up in Paud' alho - Engenho Pitangueira, PE, about $40 \mathrm{~km}$ from São Lourenço da Mata. There were 1,691 specimens of $B$. straminea used from Camorim, 1,972 specimens of $B$. straminea from Picos, and 1,735 specimens of B. glabrata from Ressaca. The procedures for collecting feces of infected mice and for later exposure of snails to miracidia were those described by Paraense and Corrêa (1989). The onset of egg laying was carefully observed on each aquarium to distinguish the molluscs exposed before the first oviposition (immature) from those exposed after having reached sexual maturity (mature). The aquaria were kept at a room temperature of $24-26^{\circ} \mathrm{C}$ throughout the experiment.

Parasitological aspects - Snails were observed daily and, if any specimen happened to die, it was fixed in Railliet-Henry's fluid and examined for developing stages of the schistosome. This procedure provided the mortality index (proportion of exposed molluscs that died during the precercarial period) on the three colonies. To characterize the duration of precercarial period and the infection index, the screening techniques used to detect the positive snails were those described by Paraense and Corrêa (1989); the specimens that survived for 70 days after exposure without shedding cercariae, were fixed, dissected and examined. From each age group in the three analyzed colonies, specimens that had emitted cercariae were separated at random to characterize the duration of the cercarial period and the rate of cercarial emission. Each infected snail was kept separately in a small aquarium until death, and to estimate the cercarial emission the procedures described by Paraense and Corrêa (1989) were followed, except for the days of exposure (Mondays, Wednesdays and Fridays in the first month, and only Wednesdays in the following months). To confirm the parasitological cure, the mollusc was anesthetized, dissected and examined.

Statistical analysis - The statistical analysis were carried out using SYSTAT 7 (SPSS 1997). In order to ascertain whether there were significant differences, the data were analyzed through Contingency Tables (comparisons of infection and mortality indices related to age of exposure and stage of sexual development), Wilcoxon's test (infection and mortality indices), Analysis of Variance and Turkey's HSD Multiple Comparison test (duration of the precercarial and cercarial periods and cercarial emission), and Pearson's coeficient (correlation between the shell diameters and parasitological aspects). $\mathrm{P}<0.05$ was considered significant.

\section{RESULTS}

Results about infection and mortality of the B. straminea and B. glabrata colonies submitted to $S$. mansoni sympatric strains, as well as the diameter of molluscs when exposed to miracidia are in Table I. For the B. straminea colony from Camorim, 217 (12.8\%) became infected, including $11(5.1 \%)$ that died carrying sporocysts in the body tissues. From the 1,474 molluscs that remained negative, 54 specimens died (3.7\%). From the 1,972 exposed molluscs of $B$. straminea from Picos, 114 $(5.8 \%)$ were infected; among them, $9(7.9 \%)$ died in the precercarial period. From the 1,858 molluses that remained negative, $16(0.9 \%)$ died in that same period. For the B. glabrata colony from Ressaca, $1,179(68 \%)$ were infected; among them, $11(0.9 \%)$ died in the precercarial period. From the $556 \mathrm{~mol}-$ luscs that remained negative, 25 (4.5\%) died. Grouping the infection and mortality data by sexual maturation of molluscs when exposed to $S$. mansoni, indices were obtained for immature and mature stages, respectively, as follow: B. straminea from Camorim, 17.9 and $4.3 \%$ of infection and 0.9 and $8.8 \%$ of mortality; $B$. straminea from Picos, 7.7 and $3.2 \%$ of infection and 0.8 and $1.9 \%$ of mortality; B. glabrata from Ressaca, 83.6 and $48.2 \%$ of infection and 1.2 and $3.1 \%$ of mortality.

The duration of the precercarial period in the B. straminea colony from Camorim was $34.8 \pm 8.62$ days (mean and standard deviation), varying from $28.6 \pm 7.33$ days, on the 16 specimens exposed at the age of 21 days, to $55 \pm 0$ days, on the two exposed at the age of 53 days. The duration of the precercarial period in the other ages was as fol- 
lows: 8 days old, $33.7 \pm 7.79$ days; 13 days old, 34.3 \pm 6.85 days; 18 days old, $36.6 \pm 9.54$ days; 83 days old, $52.5 \pm 9.81$ days; 114 days old, $40.8 \pm 9.07$ days. For $B$. straminea from Picos, the precercarial period lasted $31.9 \pm 5.42$ days, varying from $27.9 \pm$ 3.41 days, on the 19 specimens exposed at the age of 21 days, to $44 \pm 0$ days, on the only mollusc that eliminated cercariae from the ones exposed at 83 days. The duration of the precercarial period in the other ages was: 8 days old, $31.7 \pm 3.94$ days; 18 days old, $32.3 \pm 5.19$ days; 21 days old, $27.9 \pm 3.41$ days; 53 days old, $35.3 \pm 6.37$ days; 114 days old,
$32.6 \pm 3.42$ days. For $B$. glabrata, this period lasted $30.3 \pm 6.11$ days, varying from $25.4 \pm 0.52$ days, on the 10 exposed at the age of 21 days, to $33.9 \pm 5.41$ days, on the 13 exposed at 83 days. The duration of the precercarial period in the other ages was: 8 days old, $28 \pm 4.13$ days; 13 days old, $31.1 \pm 3.07$ days; 18 days old, $29.8 \pm 8.23$ days; 53 days old, $31.3 \pm 9.07$ days; 114 days old, $32.5 \pm 5.03$ days. According to the sexual maturation of molluscs the following data were obtained for imature and mature stages, respectively: $33.8 \pm 7.75$ days and $45 \pm$ 10.37 days on the specimens from Camorim; $31.3 \pm$

TABLE I

Infection and mortality of Biomphalaria straminea and Biomphalaria glabrata exposed at the ages of 8, 13, 18, $21,53,83$ or 114 days to sympatric Schistosoma mansoni

\begin{tabular}{|c|c|c|c|c|c|c|c|c|}
\hline \multirow{2}{*}{$\begin{array}{l}\text { Colonies of } \\
\text { molluscs/ } \\
\text { Strains of } \\
\text { S. mansoni }\end{array}$} & \multirow{2}{*}{$\begin{array}{l}\text { Sexual } \\
\text { stage of } \\
\text { snails }\end{array}$} & \multirow{2}{*}{$\begin{array}{l}\text { Age of } \\
\text { snails } \\
\text { (days) }\end{array}$} & \multirow{2}{*}{$\begin{array}{c}\text { Number of } \\
\text { snails } \\
\text { exposed }\end{array}$} & \multirow{2}{*}{$\begin{array}{c}\text { Shell } \\
\text { diameter } \\
(\mathrm{mm}) \\
(\mathrm{mean} \pm \mathrm{SE})\end{array}$} & \multirow{2}{*}{$\begin{array}{c}\% \text { of } \\
\text { snails } \\
\text { infected }\end{array}$} & \multicolumn{3}{|c|}{$\%$ of dead snails } \\
\hline & & & & & & + & - & total \\
\hline \multirow{7}{*}{ 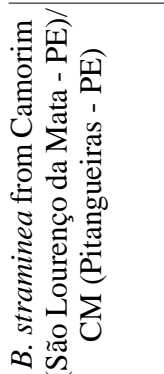 } & \multirow{4}{*}{ Immature } & 8 & 237 & $0.7 \pm 0.19$ & 30.38 & 1.39 & 0.61 & 0.84 \\
\hline & & 13 & 326 & $1.3 \pm 0.35$ & 24.23 & 2.53 & 1.21 & 1.53 \\
\hline & & 18 & 281 & $2.1 \pm 0.44$ & 7.83 & 0.0 & 0.39 & 0.36 \\
\hline & & 21 & 219 & $3.2 \pm 0.41$ & 7.76 & 0.0 & 0.99 & 0.91 \\
\hline & \multirow{3}{*}{ Mature } & 53 & 246 & $5.7 \pm 0.10$ & 1.22 & 0.0 & 0.82 & 0.81 \\
\hline & & 83 & 202 & $7.3 \pm 0.43$ & 2.97 & 33.33 & 9.69 & 10.40 \\
\hline & & 114 & 180 & $8.0 \pm 0.49$ & 10.00 & 33.33 & 16.05 & 17.78 \\
\hline
\end{tabular}

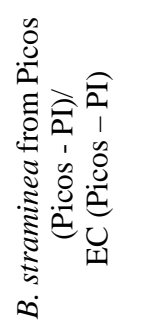

Immature

$\begin{array}{rr}8 & 334 \\ 13 & 299 \\ 18 & 297 \\ 21 & 217 \\ & \\ 53 & 234 \\ 83 & 319 \\ 114 & 272\end{array}$

$\begin{array}{lcccc}0.6 \pm 0.20 & 8.68 & 6.90 & 0.33 & 0.90 \\ 1.2 \pm 0.27 & 7.36 & 0.0 & 0.72 & 0.67 \\ 2.0 \pm 0.39 & 5.72 & 5.88 & 0.36 & 0.67 \\ 3.1 \pm 0.31 & 9.22 & 5.00 & 0.51 & 0.92 \\ & & & & \\ 6.4 \pm 0.98 & 3.42 & 12.50 & 0.44 & 0.85 \\ 8.0 \pm 1.24 & 0.94 & 66.67 & 0.63 & 1.25 \\ 8.9 \pm 0.53 & 5.51 & 13.33 & 3.11 & 3.68\end{array}$

\begin{tabular}{|c|c|c|c|c|c|c|c|c|}
\hline \multirow{4}{*}{\multicolumn{2}{|c|}{ 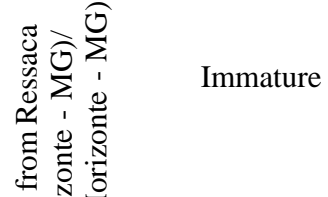 }} & 8 & 215 & $1.0 \pm 0.0$ & 58.60 & 2.38 & 2.25 & 2.33 \\
\hline & & 13 & 279 & $1.3 \pm 0.11$ & 92.47 & 0.38 & 4.76 & 0.72 \\
\hline & & 18 & 234 & $2.1 \pm 0.22$ & 93.59 & 0.46 & 26.67 & 2.14 \\
\hline & & 21 & 240 & $3.5 \pm 0.54$ & 85.83 & 0.0 & 0.0 & 0.0 \\
\hline \multirow{3}{*}{ 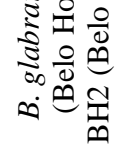 } & \multirow{3}{*}{ Mature } & 53 & 237 & $8.8 \pm 0.66$ & 62.45 & 0.0 & 4.49 & 1.69 \\
\hline & & 83 & 281 & $11.7 \pm 1.27$ & 39.86 & 0.89 & 4.14 & 2.85 \\
\hline & & 114 & 249 & $12.8 \pm 0.64$ & 44.18 & 4.55 & 5.04 & 4.82 \\
\hline
\end{tabular}

+: developing sporocysts; -: negative 
5.38 days and $34.1 \pm 5.17$ days, Picos; $29 \pm 5.49$ days and $32.6 \pm 6.58$ days, Ressaca.

As shown in Table II, the duration of the cercarial period was extremely variable for the three colonies. From the 143 Camorim snails observed, 7 $(4.9 \%)$ were anesthetized and fixed since they have stopped cercarial emission. Among these, a specimen exposed at the age of 13 days showed parasitological cure, and three specimens were observed with sporocysts in the body tissues. The duration of the cercarial period in the Camorim colony was $86.2 \pm 67.6$ days. In relation to Picos, $7(11.7 \%)$ molluscs were anesthetized and fixed since they have stopped cercarial emission, although only one specimen exposed at the age of 13 days showed parasitological cure. The duration of the cercarial period in the Picos colony was 53.6 \pm 55.87 days.

In the $B$. glabrata colony, all the molluscs died of infection and never stopped cercarial emission; the duration of the cercarial period among the 81 molluscs that emitted cercariae and were observed until death was $99.1 \pm 82.77$ days. According to the developmental stage, cercarial periods for immature and mature molluscs were, respectively: $93.9 \pm$ 66.80 days and $32.4 \pm 45.67$ days for $B$. straminea from Camorim, $67.9 \pm 59.93$ days and $25.2 \pm 32.25$ days for $B$. straminea from Picos, and 102.4 \pm 97.62 days and $95.4 \pm 62.99$ days for $B$. glabrata from Ressaca.

Overall cercarial emission for the three colonies was as follows: Camorim, $14.8 \pm 14.76$ cercariae per mollusc per day; Picos, $8.8 \pm 11.45 \mathrm{cerc} / \mathrm{mol} /$ day; Ressaca, $156.7 \pm 112.97 \mathrm{cerc} / \mathrm{mol} / \mathrm{day}$. As regards sexual maturation, cercarial emission in the immature and mature molluscs, respectively, was as follows: Camorim, $14.6 \pm 15.92 \mathrm{cerc} / \mathrm{mol} /$ day and 15.2 $\pm 13.34 \mathrm{cerc} / \mathrm{mol} / \mathrm{day}$, Picos, $6.3 \pm 9.78 \mathrm{cerc} / \mathrm{mol} / \mathrm{day}$ and $11.6 \pm 12.71 \mathrm{cerc} / \mathrm{mol} /$ day, Ressaca, $123.2 \pm 71.64$ $\mathrm{cerc} / \mathrm{mol} /$ day and $168.1 \pm 122.7 \mathrm{cerc} / \mathrm{mol} /$ day. The data regarding cercarial emission by mollusc age are given in Table II.

Statistical analysis showed that: (1) significant associations were found between age of exposure and infection index in B. straminea (Camorim, $\chi^{2}=163.0, \mathrm{p}<0.001 ;$ Picos, $\left.\chi^{2}=27.4, \mathrm{p}<0.001\right)$ as well as in B. glabrata $\left(\chi^{2}=361.3\right.$, $\left.\mathrm{p}<0.001\right)$. (2) Significant associations were also found between age of exposure and mortality index for the three colonies (B. straminea from Camorim, $\chi^{2}=148.9, \mathrm{p}<0.001$; $B$. straminea from Picos, $\chi^{2}=15.2, \mathrm{p}<0.05$; B. glabrata, $\left.\chi^{2}=17.9, \mathrm{p}<0.01\right)$. (3) Significant differences were detected in the infection and mortality indices between immature and mature stages in $B$. straminea as well as in B. glabrata (infection and mortality, respectively: Camorim, $\chi^{2}=63.83$, $\mathrm{p}<0.001, \chi^{2}=65.3, \mathrm{p}<0.001 ;$ Picos, $\chi^{2}=17.18, \mathrm{p}<0.001$, $\chi^{2}=5.1, \mathrm{p}<0.05 ;$ Ressaca, $\chi^{2}=243.7, \mathrm{p}<0.001, \chi^{2}=7.5$, $\mathrm{p}<0.01$ ). (4) Significant differences were found in the infection index between $B$. straminea from Camorim and B. glabrata $(\mathrm{Z}=2.37 ; \mathrm{p}<0.05)$, and between $B$. straminea from Picos and $B$. glabrata $(\mathrm{Z}=2.37 ; \mathrm{p}<0.05)$, but not between $B$. straminea from Camorim and B. straminea from Picos $(\mathrm{Z}=-1.52$; $\mathrm{p}>0.05)$. (5) No significant difference in the mortality index among the molluscs showing sporocysts, between $B$. straminea from Camorim and $B$. glabrata $(\mathrm{Z}=0,0 ; \mathrm{p}>0,05)$, B. straminea from Picos and B. glabrata $(\mathrm{Z}=0.33 ; \mathrm{p}>0.05)$, and $B$. straminea from Camorim and $B$. straminea from Picos $(Z=-0.11 ; p>0.05)$. (6) On the other hand, among the dead molluscs that did not show sporocysts, a significant difference was detected between $B$. straminea from Camorim and B. straminea from Picos $(Z=-2.06 ; \mathrm{p}<0.05)$, but not between B. straminea from Camorim and B. glabrata $(\mathrm{Z}=$ $0.85 ; \mathrm{p}>0.05)$ and $B$. straminea from Picos and B. glabrata $(\mathrm{Z}=1.12 ; \mathrm{p}>0.05)$. (7) Significant differences were found comparing the mortality index in each colony between positive and negative molluscs in B. straminea from Picos $(\mathrm{Z}=-2.20 ; \mathrm{p}<0.05)$ and $B$. glabrata $(\mathrm{Z}=1.99 ; \mathrm{p}<0.05)$, but not in B. straminea from Camorim $(\mathrm{Z}=-1.01 ; \mathrm{p}>0.05)$. (8) A significantly negative correlation was found between infection index and mollusc diameter in B. straminea from Camorim $(\mathrm{r}=-0.844 ; \mathrm{p}<0.05)$, but not in B. straminea from Picos $(\mathrm{r}=-0.684 ; \mathrm{p}>0.05)$ or in B. glabrata ( $\mathrm{r}=-0.660 ; \mathrm{p}>0.05)$. (9) No significant correlation was detected between mortality index and mollusc diameter in $B$. straminea from Camorim ( $r=0.665 ; \mathrm{p}>0.05), B$. straminea from Picos $(\mathrm{r}=0.580 ; \mathrm{p}>0.05)$ or B. glabrata $(\mathrm{r}=0.389 ; \mathrm{p}>0.05)$. (10) Significant differences in the duration of precercarial period were found when comparing the mollusc age in the in B. straminea (Camorim, $\mathrm{F}=9.11$, $\mathrm{p}<0.001$; Picos, $\mathrm{F}=4.08, \mathrm{p}<0.01)$ as well as in B. glabrata $(\mathrm{F}=4.51, \mathrm{p}<0.001)$. (11) Significant differences were found in the duration of precercarial period between immature and mature molluscs (Camorim, F=30.09, $\mathrm{p}<0.001$; Picos, $\mathrm{F}=5.07$, $\mathrm{p}<0.05$; Ressaca, $F=11.70, \mathrm{p}<0.001$ ). (12) Significant differences were found in the precercarial period between $B$. straminea from Camorim and $B$. straminea from Picos (HSD $=-0.033 ; \mathrm{p}<0.01)$, and also between B. straminea from Camorim and B. glabrata (HSD $=-0.056 ; \mathrm{p}<0.001)$, but not between $B$. straminea from Picos and B. glabrata $(\mathrm{HSD}=-0.023 ; \mathrm{p}>0.05)$. (13) Significant differences in the duration of cercarial period were found when comparing the mollusc age in the B. straminea colonies (Camorim, $\mathrm{F}=4.07, \mathrm{p}<0.001 ;$ Picos, $\mathrm{F}=5.55, \mathrm{p}<0.001)$, but not in B. glabrata $(\mathrm{F}=0.45, \mathrm{p}>0.05)$. (14) No significant correlation was observed between the duration of cercarial period and the mollusc diameter at the time of the first cercarial emission (Camorim, $r=0.002$, 


\section{TABLE II}

Duration of cercarial period and rate of cercarial emission of Biomphalaria straminea and Biomphalaria glabrata exposed at the ages of $8,13,18,21,53,83$ or 114 days to sympatric Schistosoma mansoni

\begin{tabular}{|c|c|c|c|c|c|c|c|}
\hline $\begin{array}{l}\text { Colonies of } \\
\text { molluscs/ } \\
\text { Strains of } \\
\text { S. mansoni }\end{array}$ & $\begin{array}{l}\text { Sexual } \\
\text { stage of } \\
\text { snails }\end{array}$ & $\begin{array}{l}\text { Age of } \\
\text { snails } \\
\text { (days) }\end{array}$ & NCP & $\begin{array}{c}\text { Cercarial } \\
\text { period } \\
\text { (days) } \\
(\text { mean } \pm \text { SE) }\end{array}$ & $\begin{array}{c}\text { Shell diameter } \\
\text { after } 1^{\text {st }} \text { cercarial } \\
\text { emission } \\
(\text { mean } \pm \text { SE })\end{array}$ & NEM & $\begin{array}{c}\text { Cercarial } \\
\text { emission } \\
(\text { mean } \pm \text { SE) }\end{array}$ \\
\hline \multirow{7}{*}{ 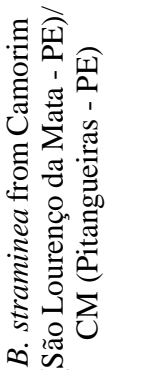 } & \multirow{4}{*}{ Immature } & 8 & 40 & $101.1 \pm 76.96$ & $3.2 \pm 1.06$ & 6 & $4.5 \pm 3.53$ \\
\hline & & 13 & 52 & $74.2 \pm 47.92$ & $3.4 \pm 0.67$ & 4 & $12.4 \pm 17.51$ \\
\hline & & 18 & 17 & $98.3 \pm 49.33$ & $4.6 \pm 0.88$ & 0 & - \\
\hline & & 21 & 16 & $135.5 \pm 87.94$ & $5.8 \pm 0.44$ & 16 & $18.9 \pm 17.19$ \\
\hline & \multirow{3}{*}{ Mature } & 53 & 2 & $108.0 \pm 132.94$ & $7.8 \pm 0.35$ & 2 & $13.3 \pm 10.82$ \\
\hline & & 83 & 4 & $20.3 \pm 25.38$ & $8.0 \pm 0.19$ & 4 & $15.7 \pm 17.15$ \\
\hline & & 114 & 12 & $23.8 \pm 16.37$ & $7.9 \pm 0.76$ & 12 & $15.4 \pm 13.54$ \\
\hline
\end{tabular}

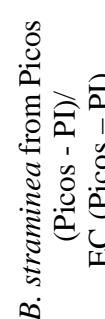

Immature
Mature

$\begin{array}{rr}8 & 2 \\ 13 & 10 \\ 18 & 9 \\ 21 & 19 \\ & \\ 53 & \\ 83 & \\ 114 & \end{array}$

$$
4.5 \pm 3.54
$$

$79.7 \pm 64.73$

$49.8 \pm 19.49$

$76.8 \pm 68.88$
$24.4 \pm 12.05$
52.0

$23.3 \pm 40.59$

$$
\begin{aligned}
& 2.5 \pm 0.71 \\
& 3.1 \pm 0.86 \\
& 4.6 \pm 0.92 \\
& 6.4 \pm 0.70
\end{aligned}
$$

$8.5 \pm 0.41$
9.0
$9.3 \pm 0.40$

\begin{tabular}{|c|c|c|c|c|c|c|c|}
\hline 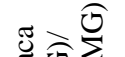 & & 8 & 11 & $121.2 \pm 132.26$ & $3.9 \pm 0.92$ & 1 & 5.5 \\
\hline 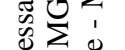 & Immature & 13 & 11 & $74.0 \pm 63.02$ & $5.0 \pm 1.29$ & 1 & 34.7 \\
\hline 量 & & 18 & 11 & $81.2 \pm 62.52$ & $7.5 \pm 2.97$ & 1 & 84.5 \\
\hline 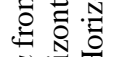 & & 21 & 10 & $136.4 \pm 114.13$ & $9.9 \pm 1.23$ & 10 & $147.8 \pm 59.98$ \\
\hline 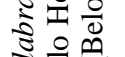 & & 53 & 12 & $107.2 \pm 72.33$ & $12.5 \pm 2.92$ & 12 & $98.7 \pm 81.74$ \\
\hline & Mature & 83 & 13 & $100.7 \pm 62.83$ & $14.3 \pm 1.01$ & 13 & $214.5 \pm 125.42$ \\
\hline & & 114 & 13 & $79.3 \pm 55.17$ & $13.7 \pm 1.38$ & 13 & $185.8 \pm 130.67$ \\
\hline
\end{tabular}

$9.3 \pm 0.40$

$12.5 \pm 2.92$

$14.3 \pm 1.01$

$13.7 \pm 1.38$
$1.5 \pm 0.71$

19.5

$6.1 \pm 9.96$

$8.4 \pm 8.50$

3.6

$14.2 \pm 14.83$

NCP; number of snails observed during of cercarial period; NEM: number of snails examined for cercarial emission.

$p>0.05$, Picos, $r=-0.152, p>0.05$, Ressaca, $r=0.216$, $\mathrm{p}>0.05$ ). (15) A significant difference in cercarial emission was found among the ages of exposure in B. glabrata $(\mathrm{F}=2.89 ; \mathrm{p}<0.05)$, but not in B.straminea (Camorim, $\mathrm{F}=1.14, \mathrm{p}>0.05$; Picos, $\mathrm{F}=1.46$, $\mathrm{p}>0.05$ ). (16) No significant difference was detected in cercarial emission between immature and mature stages (Camorim, $\mathrm{F}=0.28, \mathrm{p}>0.05$; Picos, $\mathrm{F}=3.96$, $\mathrm{p}>0.05$; Ressaca, $F=0.24, \mathrm{p}>0.05$ ). (17) Significant differences were found in cercarial emission between B. straminea from Camorim and B. glabrata
$(\mathrm{HSD}=1.096 ; \mathrm{p}<0.001)$ and also between $B$. straminea from Picos and B. glabrata from Ressaca $(\mathrm{HSD}=1.407 ; \mathrm{p}<0.001)$ and $B$. straminea from Camorim and $B$. straminea from Picos $(\mathrm{HSD}=$ $-0.311 ; \mathrm{p}<0.05)$.

\section{DISCUSSION}

In the three colonies studied, susceptibility to S. mansoni varied with mollusc age at the time of exposure, the infection index being proportionally higher in immature molluscs than in mature ones. 
This higher susceptibility in younger molluscs is not unexpected as it could be due to immune system functional immaturity, as pointed out by Dikkeboom et al. (1985), for Lymnaea stagnalis

The overall infection indices found in the present work for $B$. straminea from Camorim (12.8\%) and from Picos $(5.8 \%)$, as well as for B. glabrata $(68 \%)$, are in contrast with those found by other authors for colonies from the same geographical areas. Thus, Barbosa and Figueiredo (1970) obtained $0.6 \%$ for $B$. straminea from Camorim; Favre et al. (1995) found $0.5 \%$ for $B$. straminea from Picos; Souza et al. (1996) obtained $85.5 \%$ for $B$. glabrata from Ressaca. These discrepancies may be due to differences in methodology rather than in parasitemollusc compatibility. The present infection indices were relatively lower in both colonies of $B$. straminea than in B. glabrata, confirming observations by Souza et al. (1995).

The infection indices obtained in the present study for B. straminea from Picos and B. glabrata from Ressaca can be statistically compared to those obtained by Fernandez (1997), because there were used the same methodologies. This author obtained an infection index of $71.5 \%$, using B. glabrata from Ressaca at the age of 1,2 and 3 months. The result was not significantly different $\left(\chi^{2}=0.61 ; p>0.05\right)$ from the one obtained in the present research concerning the same age in this colony. With the colony from Picos, Fernandez (1997) obtained an overall infection index of $9.7 \%$, not significantly differing $\left(\chi^{2}=3.05 ; p>0.05\right)$ from the one obtained on this study.

The present results also show that only in $B$. straminea from Camorim the infection index differed with the diameters of the molluscs when exposed to miracidia. In $B$. straminea from Picos such difference was not detected, probably because the mean diameter $(5.8 \pm 0.46 \mathrm{~mm})$ was statistically greater than the ones from Camorim $(5.3 \pm 0.42 \mathrm{~mm})$ $(\mathrm{F}=14.7 ; \mathrm{p}<0.001)$. In relation to $B$. glabrata, the lack of a correlation between size and infection might have been caused by the low index of infection $(52.6 \%)$ in the molluscs exposed at the age of 8 days ( $1 \mathrm{~mm}$ of diameter). Therefore, if only the ages from 13 days on are considered $(1.3 \mathrm{~mm}-12.8 \mathrm{~mm}$ of diameter), a strong negative correlation is obtained $(r=0.96 ; p<0.01)$. These data agree with that of Anderson et al. (1982) who, working with molluscs from 2 to $18 \mathrm{~mm}$, observed a progressive decline on the infection index with increasing size.

The low infection index obtained in the B. glabrata molluscs exposed at the age of 8 days (Table I), comparing to the others, agrees with Cooper et al. (1992) who, working with molluscs at the ages of 4 to 70 days, obtained an infection index lower than $13 \%$ in the ones exposed at the age of 4 to 7 days $(0.96 \pm 0.03 \mathrm{~mm})$, while in the other ages the index varied from 25 to $60 \%$. These results show the necessity of including newly-born molluses in experimental exposure studies, in order to obtain a more accurate estimate of the infection index.

The age of the mollusc on the exposure to miracidia influenced the mortality. In B. straminea from Picos and Camorim the mortality index was significantly higher for the mature ones, than for the immature. In B. glabrata, the highest index occurred with the mature ones that were free from infection, comparing to the others. However, Fernandez (1997) did not detect the influence of age on the mortality using $B$. straminea (molluscs exposed at the age of 30,60 and 90 days). On the other hand, with B. glabrata, she verified the highest mortality index on the molluscs exposed at the age of 30 days. In the same way, Cooper et al. (1992), with B. glabrata from 4 to 41 days old obtained the highest mortality index on the molluscs that were 4 to 7 days old.

The mortality index in the three colonies studied here did not correlate with the diameter at the time of exposure. Barreto and Barbosa (1959) related mortality and mollusc diameter during the exposure to miracidia in B. glabrata from Pernambuco. According to these authors, molluscs measuring from 13 to $16 \mathrm{~mm}$ in diameter had a better survival, comparing to the ones measuring from 7 to $10 \mathrm{~mm}$. However, this information cannot be compared to the ones in this study, for the considered diameter for B. glabrata varied from 1 to $13 \mathrm{~mm}$.

Although these conflicts point to the need of more detailed studies in order to clarify the influence of S. mansoni infection on the survival of transmission species, the mortality indices obtained in this study were surprisingly low. If we take the mortality caused by infection into consideration, i.e., deducting that one obtained among the noninfected, there will be the following indices: $1.4 \%$ for $B$. straminea from Camorim, $7 \%$ for $B$. straminea from Picos and $0 \%$ for B. glabrata from Ressaca. Low mortality indices caused by infection were also obtained by Fernandez (1997) for $B$. straminea from Picos (0\%) and B. glabrata from Ressaca (3.6\%). These low indices are likely when the number of miracidia is somewhat small. Souza et al. (1995), using B. glabrata from Belo Horizonte exposed to $S$. mansoni sympatric, obtained a higher mortality index, comparing to the one obtained in this study, probably because the miracidian charge was 10 times higher than the one used in the present study.

The duration of the precercarial period is in accordance with those described by Favre et al. (1995) for B. straminea from Picos and B. glabrata from Belo Horizonte. In the three colonies, this period was influenced by the age of the mollusc. For 
B. straminea from Camorim this period was significantly longer than in the other two colonies; a possible reason for that result is that the $S$. mansoni strain EC, used in B. straminea from Picos, and the $\mathrm{BH} 2$ strain, used in B. glabrata from Ressaca, are kept in laboratory for a substantially longer period, comparing to the $\mathrm{CM}$ strain, used in $B$. straminea from Camorim.

The presence of infected molluscs that do not shed cercariae might characterize a delay in the $S$. mansoni development. This fact was observed in a $B$. glabrata colony known by its resistance (Newton 1953), as well as in three other highly susceptible (Paraense \& Corrêa 1963). According to these authors, there are individuals that react against the parasite, what may cause the precercarial period to be longer than expected.

The duration of the cercarial period was extremely variable in the three studied colonies, with the variation coefficient (standard deviation as a percentage of the mean) of $78.4 \%$ in $B$. straminea from Camorim, $104.3 \%$ in $B$. straminea from Picos and $83.6 \%$ in B. glabrata from Ressaca. High variation coefficients in the cercarial period were found in other studies on experimental infection. Thus, the results of Coelho and Barbosa (1956), for B. straminea from Pernambuco, revealed a variation coefficient of $122.7 \%$, for a cercarial period of around 5.2 days. Similarly, Favre et al. (1995) showed a coefficient of $104.8 \%$ for $B$. straminea from Picos (cercarial period of 24.5 days) and a coefficient of $56.2 \%$ for B. glabrata from Belo Horizonte (31.2 days). This high variability may be the result of individual differences among the molluscs.

Parasitological cure was observed in the $B$. straminea colonies only, confirming the observations by Barbosa (1975) about the higher frequency of cure in $B$. straminea than in B. glabrata. It is interesting to notice that the cure index obtained by this author for B. glabrata from Northeast Brazil, did not differ significantly $\left(\chi^{2}=0.05\right.$; $\mathrm{p}>0.05)$ from the one obtained in the present work for that species.

The developmental stage of the mollusc when exposed to miracidia did not influence on the cercarial emission rate. These results, obtained here for the first time for $B$. straminea, agree with Gérard et al. (1993) in B. glabrata. These authors, studying the sporocysts population dynamics in relation to miracidian dose and host size, showed that the cercarial emission rate on the molluscs submitted to the same miracidian dose do not differ significantly between the immature and the mature.

For B. glabrata from Ressaca, the cercarial emission rate only differed significantly between the ages of 8 and 83 days ( $\mathrm{HSD}=1.44 ; \mathrm{p}<0.05)$, and between 8 and 114 days $(\mathrm{HSD}=1.41 ; \mathrm{p}<0.05)$. The molluscs exposed at the age of 8 days had a diameter of approximately $1 \mathrm{~mm}$, whereas the ones exposed at the ages of 83 and 114 days measured more than $11 \mathrm{~mm}$. These results are compatible with the ones found by Niemann and Lewis (1990) who, working with B. glabrata from Puerto Rico, observed that molluscs exposed when measuring more than $11 \mathrm{~mm}$ eliminated a significantly higher proportion of cercariae, than the smaller ones. The significantly lower number of emitted cercariae in $B$. straminea than in B. glabrata obtained in the present work confirm the findings by Souza et al. (1983).

This work reinforces the view that the age of the mollusc when exposed to the parasite is an important variable and should be taken in to consideration in studies of parasite-mollusc compatibility. Considering that the usual methods for collecting molluscs tend to overlook those under $2 \mathrm{~mm}$ in shell diameter (Olivier \& Uemura 1973), estimates of mollusc infection in natural habitats may be underrated. Therefore, particular attention should be given to the smaller, younger molluscs when sampling natural populations.

\section{ACKNOWLEDGEMENTS}

To Dr W Lobato Paraense and Dr Lygia dos Reis Corrêa for providing facilities at the Department of Malacology of the Oswaldo Cruz Institute, and for helpful comments.

\section{REFERENCES}

Anderson RM, Mercer JG, Wilson RA, Carter NP 1982. Transmission of Schistosoma mansoni from man to snail: experimental studies of miracidiae survival and infectivity in relation to larval age, water temperature, host size and host age. Parasitology 85: 339-360.

Archibald RG, Marshall A 1932. A descriptive study of the cercaria of Schistosoma haematobium in the Sudan. J Trop Med Hyg 35: 225-228.

Barbosa FS 1975. Survival and cercarial production of Brazilian Biomphalaria glabrata and B. straminea infected with Schistosoma mansoni. J Parasitol 61: 151-152.

Barbosa FS, Figueiredo T 1970. Susceptibility of the snail intermediate hosts of schistosomiasis from northeastern Brazil to the infection with Schistosoma mansoni. Rev Inst Med Trop São Paulo 12: 198-206.

Barreto AC, Barbosa FS 1959. Qualidades de vetor dos hospedeiros de S. mansoni no Nordeste do Brasil. IV - Eliminação de cercárias de Schistosoma mansoni por Australorbis glabratus de diâmetros diversos. An Soc Biol Pernambuco 16: 13-18.

Chernin E, Antolics M 1975. Neonatal susceptibility of Brazilian Biomphalaria to Puerto Rican Schistosoma mansoni. J Parasitol 61: 377-378.

Chu KY, Massoud J, Sabbaghian H 1966. Host-parasite relationship of Bulinus truncatus and Schistosoma haematobium in Iran. 1. Effect of the age of Bulinus truncatus on the deveplopment of Schistosoma 
haematobium. Bull Wld Hlth Org 34: 113-119.

Coelho MV, Barbosa FS 1956. Qualidades de vetor dos hospedeiros de Schistosoma mansoni no nordeste do Brasil. III - Duração da infecção e eliminação de cercárias em Tropicorbis centimetralis. Pub Avulsas Inst Aggeu Magalhães 5: 21-30.

Cooper LA, Ramani SK, Martin AE, Richards CS, Lewis FA 1992. Schistosoma mansoni infections in neonatal Biomphalaria glabrata snails. J Parasitol 78: 441446.

Dikkeboom R, Knaap WPW, Meuleman EA, Sminia T 1985. A comparative study on the internal defence system of juvenile and adult Lymnaea stagnalis. Immunology 55: 547-553.

Favre TC, Bogéa T, Rotenberg L, Silva HS, Pieri OS 1995. Cercarial emergence of Schistosoma mansoni by Biomphalaria glabrata and B. straminea. Mem Inst Oswaldo Cruz 90: 565-567.

Fernandez MA 1997. Schistosoma mansoni infections in the first three months of life of sympatric intermediate hosts from Brazil. Mem Inst Oswaldo Cruz 92: 27-29.

Gérard C, Moné H, Théron A. 1993. Schistosoma mansoni - Biomphalaria glabrata: dynamics of the sporocyst population in relation to the miracidial dose and the host size. Can J Zool 71: 1880-1885.

Michelson EH, Dubois L 1978. Susceptibility of Bahian populations of Biomphalaria glabrata to an allopatric strain of Schistosoma mansoni. Am J Trop Med Hyg 27: 782-786.

Moore DV, Thillet CJ, Carney DM, Meleney HE 1953. Experimental infection of Bulinus truncatus with Schistosoma haematobium. J Parasitol 39: 215-222.

Newton WL 1953. The inheritance of susceptibility to infection with Schistosoma mansoni in Australorbis glabratus. Exp Parasitol 2: 242-257.

Niemann GM, Lewis FA 1990. Schistosoma mansoni: influence of Biomphalaria glabrata size on susceptibility to infection and resultant cercarial productions. Exp Parasitol 70: 286-292.

Olivier LJ, Uemura K 1973. Techniques, statistical methods and recording forms. In N Ansari, Epidemiology and Control of Schistosomiasis, Karger, Basel and University Park Press, Baltimore, p. 620-748.

Paraense WL, Corrêa LR 1963. Variation in susceptibility of populations of Australorbis glabratus to a strain of Schistosoma mansoni. Rev Inst Med Trop São Paulo 5: 15-22.

Paraense WL, Corrêa LR 1989. A potential vector of Schistosoma mansoni in Uruguay. Mem Inst Oswaldo Cruz 84: 281-288.

Raymond KM, Probert AJ 1992. The effect of age and stage reproductive development of Bulinus jousseaumei on cercarial production of Schistosoma haematobium. J Med Appl Malacol 4: 121-123.

Richards CS 1970. Genetics of a molluscan vector of schistosomiasis. Nature 227: 806-810.

Richards CS 1973. A potential intermediate host of Schistosoma mansoni in Grenada. J Parasitol 59: 111.

Souza CP, Araújo N, Azevedo MLL 1983. Estudo da potencialidade de populações de Biomphalaria straminea do Estado de Minas Gerais, como hospedeiras do Schistosoma mansoni. Mem Inst Oswaldo Cruz 78: 251-256.

Souza CP, Jannotti-Passos LK, Freitas JR 1995. Degree of host-parasite compatibility between Schistosoma mansoni and their intermediate molluscan hosts in Brazil. Mem Inst Oswaldo Cruz 90: 5-10.

Souza CP, Jannotti-Passos LK, Vieira IBF, Sampaio IBM 1996. Schistosoma mansoni: níveis de infecciosidade para os moluscos hospedeiros intermediários do Brasil. Rev Soc Brasil Med Trop 29: 11-16.

SPSS 1997. SYSTAT 7: Statistics. SPSS Inc., Chicago, $751 \mathrm{pp}$. 